УДК 342.951

DOI https://doi.org/10.32837/apfs.v0i29.962

B. М. Попович

ORCID ID: https://orcid.org/0000-0002-9288-3765 доктор філософських наук, професор, завідувач кафедри соиіальної роботи та психологї̈ Національного університету «Запорізька політехніка» В. М. Демяненко
ORCID ID: https://orcid.org/0000-0002-7004-7889
магістрантка кафедри соиіальної роботи та психологї
Національного університету «Запорізька політехніка»

\title{
КОРУПЦІЙНИЙ ДОСВІД, ЧИННИКИ І МЕХАНІЗМИ ПРОТИДІЇ КОРУПЦІЇ В СОЦІАЛЬНІЙ СФЕРІ (НА ПРИКЛАДІ ЗАПОРІЗЬКОЇ ОБЛАСТІ)
}

Постановка проблеми в загальному вигляді. Корупцію як соціальне явище в сучасній соціологічній науці пов'язують насамперед із дисфункціональністю соціальних процесів у перехідних або транзитивних суспільствах, яка може охоплювати всі сфери соціального простору, що виражається в соціальному феномені, за твердженням О. Стегнія $[9$, с. 9], «всеосяжної корупції». Саме в транзитивних суспільствах (до якого належить і українське суспільство) корупція досягає найвищого рівня розповсюдженості, що актуалізуе проблему розробки й впровадження моделі протидії корупції як системи соціальних механізмів ії подолання, запобігання та попередження.

Аналіз останніх досліджень i публікацій. Складність та актуальність вивчення корупції як соціального феномена зумовлює підвищений інтерес з боку дослідників до проблеми. Поглибленому дослідженню феномену присвячені роботи Л. Багрій-Шахматова, О. Дульського, А. Закалюка, В. Зеленецького, М. Мельника, А. Міхненка, М. Михальченка, Є. Невмержицького, С. Омельченка, Б. Романюка, О. Стегнія, T. Супрун, В. Трепака, О. Терещука, О. Ярмиша й інших. Актуальним соціальним питанням є створення умов для протидії поширення корупції та корупційних практик, тому важливою науковою проблемою є систематизація соціальних механізмів протидії корупції в соціологічному дискурсі, якої в джерельному масиві публікацій натепер не досить.

Формулювання цілей статті. Метою дослідження є виокремлення особливостей корупційного досвіду населення, чинників і механізмів протидії корупції в соціальній сфері (на прикладі Запорізької області).

Виклад основного матеріалу дослідження. Корупція - багатогранне поняття, що містить безліч аспектів економічного, правового, політичного характерів, а тому його слід розглядати в міждисциплінарному контексті. Тому важливо зауважити, що до визначення корупції існує різноманіття підходів. Багато хто з дослідників називають це явище кримінологічним, хоча $є$ й така думка, що «корупція - поняття не стільки правове, скільки соціальне й моральне» [2, с. 91].

Професор Н. Кузнецова пропонує розглядати корупцію не тільки як правове, а і як соціальне, економічне й моральне явище, що завдає шкоди нормальному функціонуванню моральних і правових відносин у суспільстві й державі [6, с. 22]. Цей підхід вважається найвдалішим, бо корупцію не можна розглядати тільки в правовому аспекті. Адже, ігноруючи інші сторони корупції, які характеризують її як соціальне, політичне, економічне явище, неможливо повністю визначити природу походження терміну «корупція».

Схоже визначення дає М. Мельник: «Корупція - це багатоаспектне соціально-економічне, політичне, правове й моральне явище, що складається із цілого комплексу протиправних дій і неетичних вчинків. Корупція - це не стільки юридична, скільки соціальна й економічна проблема. Як правова категорія, корупція - збірне правове поняття, яке охоплює сукупність взаємопов'язаних правопорушень» [7, с. 34].

Соціологічний підхід до теоретичного аналізу корупції передбачає аналіз різноманіття нормативних систем і соціальних факторів, що спричиняють корупційну поведінку, й дає змогу показати диференційованість оцінок феномена різними суб'єктами. Корупція в соціологічної інтерпретації усвідомлюється як форма соціальних відносин, передбачає аналіз ї̈ як форми взаємодії суб'єктів, що володіють різним обсягом ресурсів у межах різноманітних інститутів як нормативних систем.

Для дослідження особливостей прояву, особистого досвіду й соціокультурних і соціально-правових чинників корупції та корупційних практик у соціальній сфері було проведено масове соціологічне опитування серед населення Запорізької області (n=500, листопад 2020 р.). 
Результати дослідження вказують на те, що $66 \%$ опитаних зазначили, що вони стикалися 3 проявами корупції протягом останніх дванадцяти місяців, причому $25 \%$ респондентів відзначили такий корупційний досвід у соціальній сфері - у сфері охорони здоров'я, освіти, соціального захисту й соціального обслуговування. Слід зазначити, що серед тих, хто має корупційний досвід, 56,5\% мають досвід вимагання хабарів і $35,5 \%$ - досвід добровільних хабарів, $8 \%$ опитаних використовували «зв'язки». Натепер більший досвід корупції мають люди середнього віку (30-44 роки), більш освічені й більш заможні громадяни.

На рис. 1 представлено середні показники корупційного досвіду населення залежно від суспільних сфер та інститутів.

Отже, згідно з результатами опитування виявлено деякі особливості прояву корупційних практик у різних сферах суспільного життя: 1) у сфері охорони здоров'я домінує: практика купівлі медикаментів і витратних матеріалів (56\%), сплата за медичну послугу як «добровільний внесок" через касу (20\%), добровільна сплата лікарю за медичну послугу (13\% ), примусова сплата лікарю за медичну послугу (11\%), використання особистих зв'язків (8); 2) у сфері освіти переважають обов'язкові благодійні внески (особливо в дитячих садках і середніх школах) і подарунки вихователям, вчителям, викладачам $(72 \%)$, у вищих навчальних закладах (далі - ВН3) - неофіційні сплати за заліки й іспити $(43 \%)$; 3 ) у судовій системі - використання особистих зв'язків і грошові винагороди, причому $73 \%$ опитаних не вказали ніяких неформальних практик, що, можливо, пов'язано з острахом за власну безпеку (теж саме можна казати й про корупційні практики в правоохоронній системі); 4) серед адміністративних і соціальних послуг корупційні практики виявлено під час оформлення субсидій $(60 \%)$, отримання довідок $(24 \%)$, оформлення соціальних виплат $(10 \%)$.

Поширення корупції як соціального явища підсилюється багатьма чинниками. Наприклад, В. Трепак серед таких факторів, які перешкоджають процесам подолання корупції в українському суспільстві, виділяє: 1) напруженість у соціально-економічній сфері, що створює умови для розповсюдження корупційних практик у

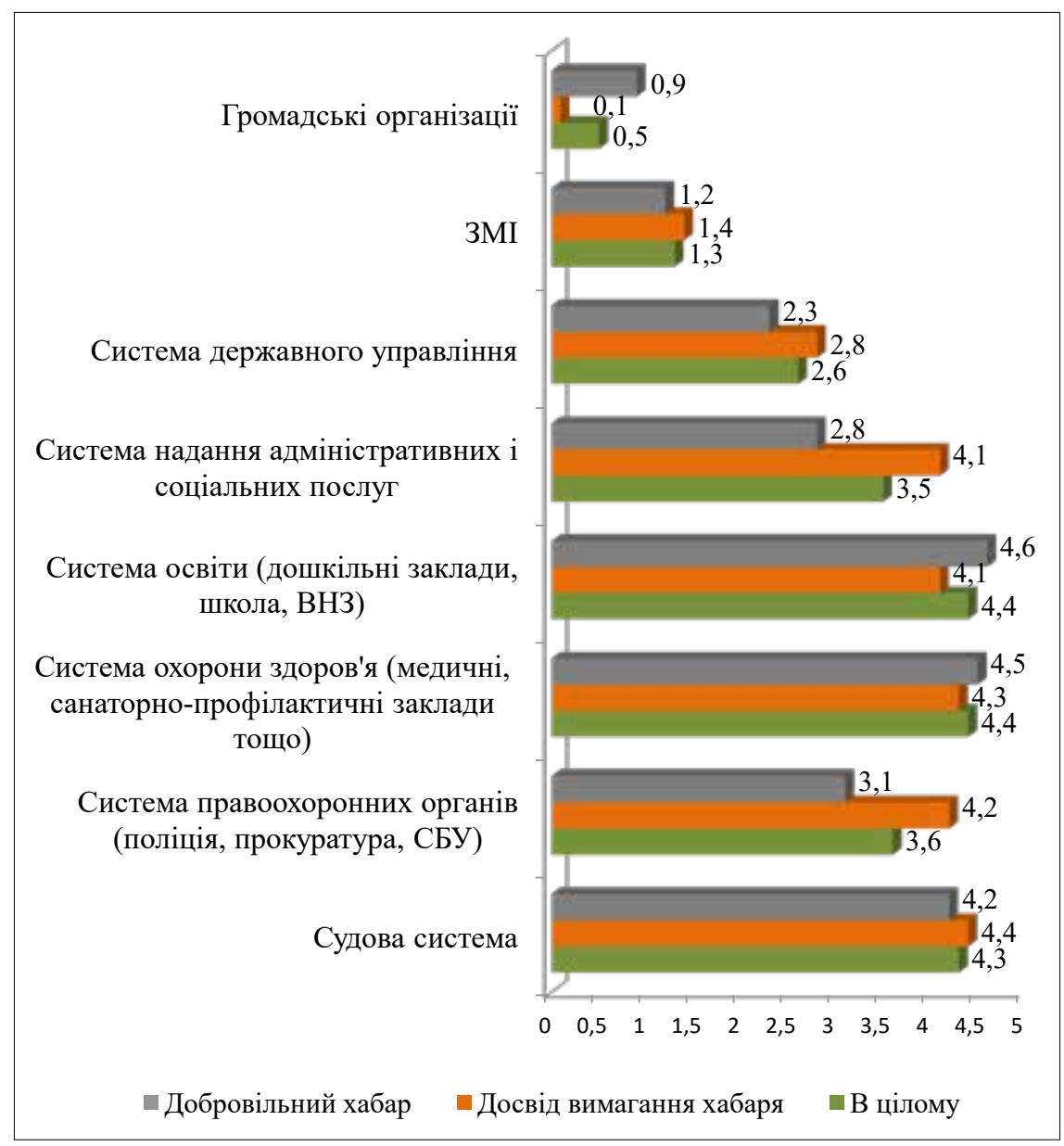

Рис. 1. Оцінка сприйняття корупції залежно від форм корупційного досвіду в різних суспільних сферах та інститутах (серед респондентів, які мають корупційний досвід) 
ринкових відносинах, уповільнюе формування середнього класу в суспільстві; 2) соціокультурні особливості менталітету, нормативно-етичної специфіки соціальної поведінки, заснованої на ціннісній ідеї патерналізму держави; 3) уявлення населення щодо органів державної влади та її представників як особливої соціальної інституції та соціальної групи, що наділені певними привілеями й статусними перевагами й діють на благо власних і корпоративних інтересів [10, с. 235]. Л. Білінська виділяє такі групи факторів та умов розвитку корупції:1) економічні (несприятливий режим діяльності підприємств; відсутність прозорості багатьох економічних процесів); 2) правові (відсутність цілісної системи антикорупційних засобів, невизначеність відповідальності за корупційні діяння тощо); 3) організаційно-управлінські (відсутність чіткої регламентації діяльності посадових осіб, фаворитизм, кронізм, непотизм тощо); 4) соціально-психологічні (нерозвиненість громадянської свідомості, професійна й моральна деформація посадовців тощо) [1, с. 140]. Саме тому появи й специфіка корупції, а також формування системи механізмів протидії корупції та корупційних практик залежить від економічних, соціальних, політичних змін, ментальних і культурних особливостей розвитку нашого суспільства.

Соціокультурні й соціально-психологічні чинники корупційних практик у перехідному українському суспільстві виділяють О. Креденцер, В. Лагодзінська, О. Ковальчук: 1) наслідки радянського типу соціальної взаємодії в системі «влада (номенклатура, чиновники, керівники) - громадяни» ; 2) особливості традиційного українського менталітету, традиційної ціннісно-нормативної системи; 3) кризовий стан суспільної свідомості - високий рівень аномійної деморалізованості населення; 4) виникнення нових соціальних груп - деформація соціальної структури суспільства тощо [5, с. 48-55].

Таким чином, сутністю корупції в перехідному суспільстві виступає легітимізація та інституціоналізація неформальної нормативної системи, яка породжує корупційні відносини на макрорівні (держава, соціальні підсистеми), мезорівні (організації, установи, підприємства) й мікрорівні (корупційні взаємодії індивідуальних акторів - побутова корупція). Виникнення та інституціоналізація корупційних практик здійснюється під впливом багатьох чинників, вага яких може варіюватися залежно від цивілізаційного й суспільного розвитку країни, політичної системи, культурних і ментальних особливостей. Для перехідних суспільств, де відбувається трансформація соціальної, економічної та політичної системи на всіх рівнях, на нашу думку, характерний комплексний і системний вплив різних груп чинни- ків, що формують неформальні норми й правила суспільних відносин і відповідну соціальну структуру, яка підтримує їх легітимізацію.

На рис. 2 представлено результати опитування щодо домінівних чинників поширення корупції в соціальній сфері.

Найчастіше провідною причиною корупції називалось прагнення чиновників використовувати службове становище заради особистої вигоди $(30,2 \%)$. Допомагає їм у цьому вище керівництво країни через своє небажання боротися з корупцією $(26,3 \%)$ і саме населення, яке звикло в такий спосіб розв'язувати власні проблеми $(23,1 \%)$. На недостатній внутрішній контроль в органах влади вказали $14,5 \%$ опитаних, а близько $13 \%$ респондентів переконані, що спричинює корупцію занадто складне й недосконале законодавство України. Слід зазначити, що «узвичаєність», "рутинізація» корупційних практик як фактор складає майже 50\% від запропонованих тверджень, а фактори зовнішнього впливу (переважно як бездіяльність держави) - майже 80\% .

Отже, соціальними чинниками корупційних практик в українському суспільстві за результатами емпіричного дослідження виділено такі групи: 1) соціокультурні чинники (домінування в суспільній свідомості уявлень про корупцію як невіддільну особливість українського менталітету, яка пронизує все суспільство, що породжує феномен «всеосяжної корупції»; амбівалентність i стереотипізація в сприйнятті корупції - як деструктивне й негативне соціальне явище, так i необхідна умова соціальних відносин; пасивний тип соціальної поведінки й реакції на корупційні діяння, сприйняття таких ситуацій як усталених і незмінних; на ціннісному рівні корупція виступає як рутинізоване, повсякденне явище в українському суспільстві, що закріплене як неформальна соціальна практика у взаємовідносинах влади й суспільства, надавачів та отримувачів соціальних і адміністративних послуг); 2) соціально-правові чинники (недосконалість антикорупційного законодавства; обмеженість громадського контролю за діяльністю органів влади й окремих корупціогенних сфер соціального життя; низький рівень розвитку громадянського суспільства; низький рівень правової та громадянської культури); 3) соціально-економічні чинники (нестабільна соціально-економічна ситуація; високий показник «тіньової» економіки; злиття великого бізнесу (олігархічних груп) 3 органами влади на всіх рівнях державного управління; розмитість норм і правил економічних відносин і транзакцій).

Нині існують декілька моделей і підходів у протидії корупції, які ефективно застосовуються різними країнами. Так, М. Кікалішвілі виділяє дві базові моделі протидії корупції: сінгапурська 


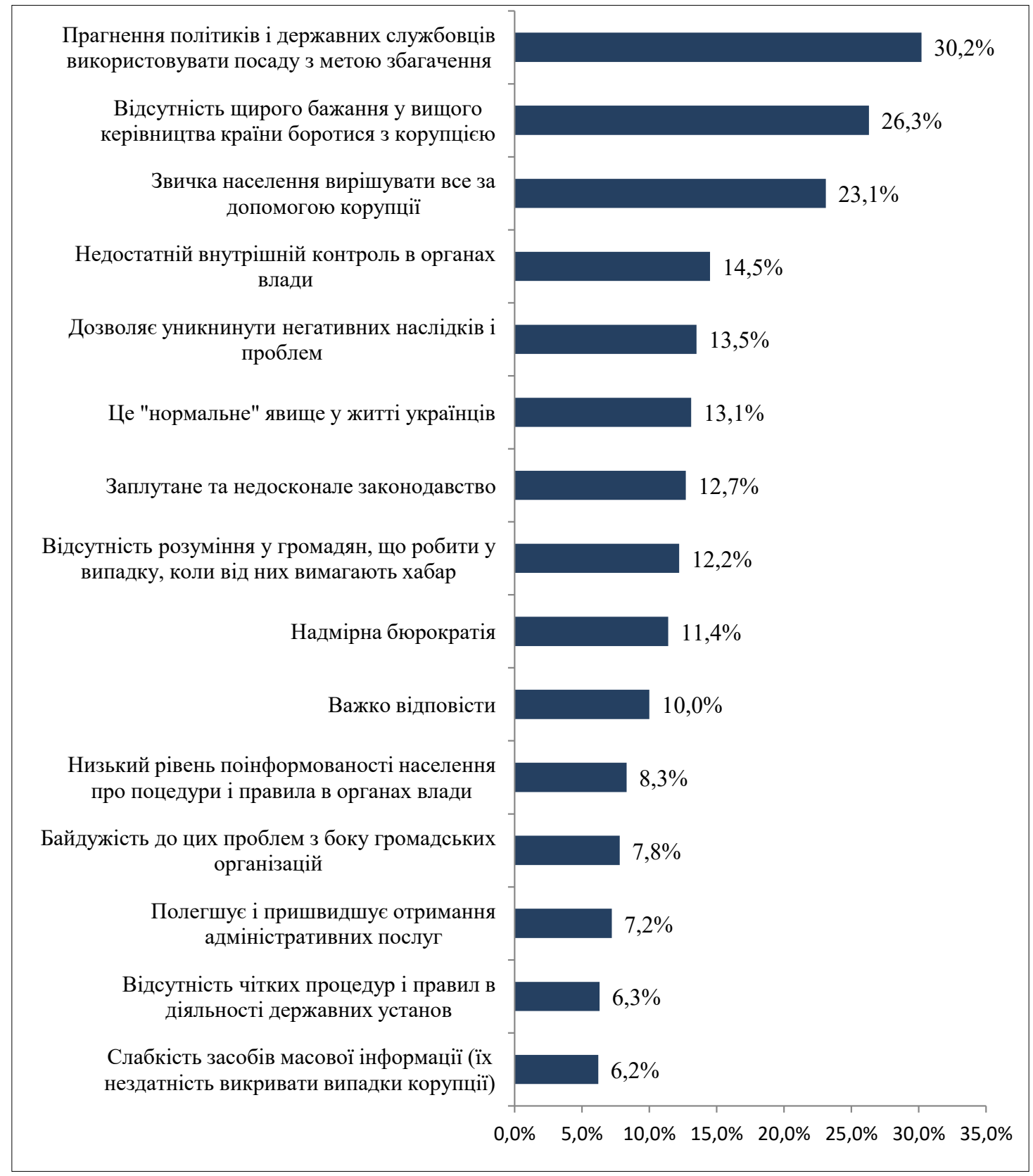

Рис. 2. Основні причини корупції в соціальній сфері (можна було обрати декілька варіантів)

модель (азіатська) й шведська модель (європейська / скандинавська) [4, с. 125]. Перша модель характеризується швидким досягненням результату через зведення корупції до прийнятного для всіх членів суспільства рівня на основі вертикального впливу на корупцію. Друга модель - горизонтальна, яка передбачає не тільки санкції нормативно-правового й кримінального характеру, але й превентивну й просвітницьку роботу з громадянами й державними службовцями, формуючи нетерпимість і неприпустимість корупції та корупційних практик у суспільстві, а це своєю чергою потребує зусиль як державних органів влади, так і громадськості. Звичайно, в різних країнах застосування цих моделей має свою спе- цифіку 3 урахуванням культурно-історичних особливостей, усталених демократичних практик взаємодії держави й суспільства, політико-ідеологічних орієнтацій і ціннісно-нормативних особливостей національного менталітету.

Власну позицію має К. Буряк, яка зазначає, що існують два основні підходи в боротьбі з корупцією: перший підхід у боротьбі з корупцією передбачає створення сприятливих соціально-економічних умов, які мінімізують корупціогенні ризики в суспільстві; другий підхід спрямований на здійснення суворого контролю та застосування жорстких методів покарання за корупційні дії [3, с. 357]. Основою реалізації системи механізмів протидії корупції авторка 
вбачає у створенні спеціальних органів антикорупційних органів, серед яких Б. Романюк виділяє декілька моделей, які відрізняються за формою, функціями й завданнями, мають певні національні ознаки й особливості: «багатоцільові органи, які мають повноваження правоохоронних органів, а також здійснюють превентивні функції; спеціалізовані служби, управління та / або відділи з боротьби проти корупції в системі правоохоронних органів; інституції із запобігання корупції, розроблення відповідної політики й координації [8, с. 11]. Отже, в такому векторі виділення моделей протидії корупції провідним принципом є принцип створення організаційно-інституційної структури в системі протидії корупції та корупційним практикам.

Таким чином, аналіз різних наукових підходів дозволяє виділити принаймні дві базові моделі протидії корупції: перша модель - вертикальна, де вплив на поширення корупції та корупційних практик здійснюється вертикально, в основі якого лежать переважно репресивні (переслідування, кримінальна відповідальність) механізми, жорсткі нормативно-правові санкції та соціальний контроль; друга модель - горизонтальна (модель системного усунення чинників корупціі), яка передбачає застосування репресивних методів, соціальний контроль і превентивні механізми, пов'язані із залученням громадськості, формуванням «антикорупційних" імперативів у суспільстві, високого рівня правової культури й соціальної відповідальності на основі принципів демократичного устрою суспільного життя.

Висновки. За результатами теоретичного й емпіричного аналізу нами зроблено такі висновки:

1. Інституціоналізація корупції як соціального явища відбувається як легітимізація неформальних соціальних практик взаємодії, тобто корупційні практики виступають як нормативні (хоча й девіантні) форми соціальної поведінки, заміщуючи моральні стандарти суб'єктивними уявленнями про соціальну взаємодію, що спричиняє закріплення корупції в організаційно стійких формах, ціннісно-нормативній системі й створенні асоціальних форм контролю та регуляції.

2. Виявлено такі соціальні чинники поширення корупції та корупційних практик у соціальній сфері: соціокультурні чинники (домінування в суспільній свідомості уявлень про корупцію, яка пронизує все суспільство, що породжує феномен "всеосяжної корупції" та відтворюється як неформальна соціальна практика); соціально-правові чинники (неефективність взаємодії громадськості й держави в здійсненні соціального контролю в окремих корупціогенних сферах соціального життя); соціально-економічні чинники (нестабільна й кризова соціально-економічна ситуація).

3. Виокремлено соціальні механізми протидії корупції: соціальні механізми нормативноправової регуляції системи протидії корупції спрямовані на формування національного антикорупційного законодавства й соціальної моделі протидії корупції; соціальні механізми інституційно-організаційного забезпечення спрямовані на формування системи антикорупційних органів; соціальні механізми інформаційно-комунікаційної взаємодії соціальних суб'єктів протидії корупції являють собою засоби ефективної соціальної взаємодії між державою та громадянами, різними секторами суспільства, ЗМІ й суспільством.

\section{Jimepamypa}

1. Білінська Л.В. Корупція як соціальне, психологічне і моральне явище. Науковий вісник Міжнародного гуманітарного університету. Сер.: Юриспруденนія. 2013. № 6. Т. 1. С. 138-141.

2. Большой толковый социологический словарь (Collins). Том 1 (A - 0) / Пер. с англ. Москва : Вече, ACT, $1999.544 \mathrm{c}$.

3. Буряк К.М. Особливості антикорупційного законодавства в країнах Європейського Союзу. Підприємництво, господарство і право. Міжнародне право. 2020. № 2. C. 356-360.

4. Кікалішвілі М.В. Західноєвропейські моделі стратегії протидії корупційній злочинності. Вчені записки ТНУ імені В.I. Вернадського. Серія: юридичні науки. 2019. № 6. Т. 30 (69). С. 124-130.

5. Креденцер О.В., Лагодзінська В.І., Ковальчук O.C. Теоретичний аналіз поняття «соціальна напруженість»: міждисциплінарний підхід. Актуальні проблеми психології : збірник наук. праць Ін-ту психології імені Г.С. Костюка НАПН України. 2016. Том I : Організаційна психологія. Економічна психологія. Соціальна психологія. Вип. 45. С. 48-55.

6. Кузнецова Н.Ф. Коррупция в системе уголовных преступлений. Вестник МГУ. Сер. 11. 2017. № 1. C. 21-26.

7. Мельник М.I. Корупція - корозія влади (соціальна сутність, тенденції та наслідки, заходи протидіï) : монографія. Київ : Юридична думка, 2004. 400 с.

8. Романюк Б.В. Світовий досвід створення та функціонування інституцій 3 попередження та боротьби з корупцією. Науково-практичний журнал. 2009. № 21. С. 9-16.

9. Стегній О.Г. Феномен всеохоплюючої корумпованості в сучасному українському суспільстві. Український соиіум. 2012. № 1 (40). С. 7-22.

10.Трепак В.М. Міжнародний досвід запровадження системи заходів антикорупційної спрямованості. Юридичний часопис Національної академії внутрішніх справ. 2015. № 2 (10). С. 233-246. 


\section{Анотація}

Попович В. М., Демяненко В. М. Корупційний досвід, чинники і механізми протидії корупції в соціальній сфері (на прикладі Запорізької області). - Стаття.

У дослідженні обгрунтовано, що корупція є явищем не тільки правовим, але й соціальним, економічним і моральним; це завдає шкоди нормальному функціонуванню моральних і правових відносин у суспільстві й державі; корупцію не можна розглядати тільки в правовому аспекті, тому що, ігноруючи інші сторони корупції, які характеризують її як соціальне, політичне, економічне явище, важко дослідити її природу походження, не вдасться з'ясувати її вплив, прояви й способи протидії такому явищу.

Виявлено деякі особливості прояву корупційних практик у таких сферах суспільного життя, як сфера охорони здоров'я; сфера освіти; судова система; сфера адміністративних і соціальних послуг.

У статті виділено сучасні практико-орієнтовані соціальні механізми попередження, запобігання та протидії корупції як соціального явища, що в умовах перехідного суспільства набуває інституціональних ознак. Надано соціологічну інтерпретацію корупції як інституціоналізацію та легітимізацію неформальних соціальних відносин, що виявляється в деформації ціннісно-нормативної системи суспільства. Дослідження спрямоване на спробу виокремлення проявів корупції з досвіду населення та аналізу можливості протистояти цьому процесу. Соціальними чинниками корупційних практик у соціальній сфері українського суспільства за результатами емпіричного дослідження виділено такі групи: соціокультурні чинники, які пов'язані з домінуванням у суспільній свідомості уявлень про корупцію як невіддільну особливість українського суспільства; соціально-правові чинники, які є наслідком низького рівня розвитку правової культури й громадянського суспільства; соціально-економічні чинники, породжені економічною кризою. Виокремлено соціальні механізми протидії корупції в соціальній сфері: соціальні механізми нормативно-правової регуляції системи протидії корупції; соціальні механізми інституційно-організаційного забезпечення; соціальні механізми інформаційно-комунікаційної взаємодії соціальних суб'єктів протидії корупції.

Ключові слова: корупція, корупційні практики, перехідне суспільство, інституціоналізація корупції, соціальні чинники корупції, соціальні механізми протидії корупції.

\section{Summary}

Popovych V. M., Demianenko V. M. Corruption experience, factors and mechanisms for countering corruption in the social sphere (by example Zaporizhzhia region). - Article.

The study substantiates that corruption is not only a legal phenomenon, but also social, economic and moral, which damages the normal functioning of moral and legal relations in society and the state; corruption cannot be considered only in the legal aspect, because ignoring other aspects of corruption, which characterize it as a social, political, economic phenomenon, it is difficult to study its nature of origin, it is impossible to determine its impact, manifestations and ways to counteract this phenomenon.

Some features of manifestation of corrupt practices in such spheres of public life as: the sphere of health care; the sphere of education; in the judicial system; in the field of administrative and social services.

The article highlights modern practice-oriented social mechanisms for precautioning, preventing and combating corruption as a social phenomenon that acquires institutional characteristics in a transitional society. The sociological interpretation of corruption as institutionalization and legitimization of informal social relations, which manifests itself in the deformation of the value-normative system of society, is provided. The study is aimed at trying to isolate the manifestations of corruption from the experience of the population and analyze the possibility of resisting this process. According to the results of an empirical study, the following groups have been identified as social factors of corruption practices in the social sphere of Ukrainian society: sociocultural factors associated with the dominance in public consciousness of ideas about corruption as an integral feature of Ukrainian society; social and legal factors that are a consequence of the low level of development of legal culture and civil society; socio-economic factors generated by the economic crisis. The social mechanisms of combating corruption in the social sphere are highlighted: social mechanisms of normative legal regulation of the anti-corruption system; social mechanisms of institutional and organizational support; social mechanisms of information and communication interaction of social actors in the fight against corruption.

Key words: corruption, corrupt practices, transitional society, institutionalization of corruption, social factors of corruption, social mechanisms of combating corruption. 